\title{
Klorin, dari PDAM hingga Suriah
}

Gede H. Cahyana

Dimuat di Pikiran Rakyat, 20 April 2017

Penguasa Suriah telah menggunakan senjata kimia klorin sejak 2012. Yang terakhir digunakan di kota Khan Syaikhun, Provinsi Idlib Selatan pada awal April 2017. Korban tewas mencapai 100-an orang dan 500-an terluka. Penggunaan senjata kimia termasuk kejahatan perang karena yang menjadi korban tidak hanya tentara dan milisi tetapi juga bayi, anak-anak, lansia, hewan ternak, dan tanaman. Bahkan flora - fauna di tanah dan air seperti ikan dan biota lainnya ikut mati. Mayoritas korban dengan kondisi badan tanpa luka dan radius korbannya bisa sejauh gas tersebut terhembus angin.

Klorin seperti pisau bermata dua, memiliki manfaat sekaligus mudarat. PDAM memanfaatkan klorin untuk melindungi manusia dari wabah penyakit menular lewat air sedangkan penguasa Suriah menggunakannya untuk membunuh rakyatnya dengan mudah dan cepat.

\section{Karakteristik}

Klorin pertama kali digunakan sebagai disinfektan, biasa disebut proses klorinasi, dalam penyediaan air minum di Jersey City, New Jersey, Amerika Serikat tahun 1908 oleh George Johnson dan John Leal. Artinya, sejarah disinfeksi identik dengan sejarah klorinasi. Di Indonesia, kalau orang menyebut disinfeksi air PDAM berarti 99,9\% adalah klorinasi. Senyawa ini ditemukan oleh ahli kimia yang juga apoteker asal Swedia bernama Scheele (1742 - 1786).

Dalam sistem periodik (tabel semua unsur kimia berikut sifat-sifatnya), klorin termasuk golongan halogen (VIIA) yang memiliki 7 elektron di kulit terluar. Tujuh elektron ini sangat stabil sehingga cenderung mengoksidasi pada setiap reaksi kimia (oksidator kuat) untuk melengkapi jumlah elektronnya menjadi delapan di kulit terluar (outer shell). Pada suhu kamar klorin berwujud gas sehingga klor yang larut cenderung menguap atau tervolatilisasi ke udara. 
PDAM menggunakan klorin di dalam proses disinfeksi, selain kaporit ( $\underline{\mathrm{kalsium}}$ hipoklorit, $\left.\mathrm{Ca}(\mathrm{OCl})_{2}\right)$. Nama lainnya ialah bleaching powder atau puyer kelantang atau chlorinated lime. Biasa digunakan untuk membasmi bakteri, algae dan bau. Setelah diinjeksikan atau dibubuhkan ke dalam air di reservoir, kisaran waktu kontaknya antara 15 - 30 menit. Dosis total klor bervariasi antara $0,2-40 \mathrm{mg} / \mathrm{l}$. Keuntungan menggunakan zat ini ialah adanya sisa klor, biasanya antara $0,2-0,5 \mathrm{mg} / \mathrm{l}$. Sisa klor ini dibutuhkan apabila di ruas pipa distribusi terjadi rekontaminasi bakteri yang masuk ke dalam pipa akibat kebocoran. Sisa klor inilah yang diharapkan mampu membasmi bakteri di dalam air kotor itu.

Karakterisitik klorin sebagai biosida antara lain (1) toksik bagi mikroba pada konsentrasi yang tidak berbahaya bagi manusia - hewan; (2) cepat bereaksi membunuh bakteri dengan waktu kontak yang singkat; (3) tahan lama sehingga mampu menanggulangi rekontaminasi di zone distribusi; (4) ekonomis (murah) dan mudah diperoleh; (5) mudah dianalisis di laboratorium; dan (6) mudah menentukan dosisnya. Tentu saja makna tidak berbahaya bagi manusia tersebut harus tetap mengacu pada upaya keamanan dengan melaksanakan prosedur operasi standar (SOP) yang berlaku. Misalnya, menggunakan tutup hidung dan mulut yang tepat.

Namun demikian, pada saat yang sama klorin pun bereaksi dengan zat organik di dalam air lalu membentuk THM (trihalomethanes) yang karsinogenik, yaitu sebagai pencetus kanker. Serentetan data awal dari percobaan pada binatang menyatakan bahwa ada korelasi antara klorinasi dan penyakit jantung (kardiovaskuler). Selain itu juga bisa terjadi iritasi terhadap selaput lendir, mata, dan kulit.

Varian lainnya adalah klor dioksida, $\mathrm{ClO}_{2}$, masih ada sangkut-pautnya dengan rumpun senyawa klor. Menurut ahli lingkungan, Droste di dalam buku Water and Wastewater Treatment, daya oksidasi senyawa ini 2,5 kali klorin. Lebih efektif dibandingkan dengan klorin apalagi kaporit. Salah satu keunggulannya dibandingkan dengan klorin ialah tidak memproduksi THM yang mutagenik dan karsinogenik itu, tetapi justru mengurangi timbulan (produksi) zat yang memicu pembentukan atau prekursor THM. 
Efisiensinya pun tidak bervariasi terhadap $\mathrm{pH}$ air sebagaimana klorin dan kaporit yang dipengaruhi oleh $\mathrm{pH}$. Juga mampu mengoksidasi besi dan mangan dengan baik daripada klorin. Hanya saja perlu hati-hati karena gas klor dioksida ini sangat reaktif - eksplosif jika kena cahaya. Oleh sebab itu, gas ini dibuat di lokasi injeksinya (di instalasinya atau onsite) dengan proses reaksi antara klorin dan natrium hipoklorit $(\mathrm{NaOCl})$.

\section{Hati-hati dan hati}

Berkaitan dengan klorin yang notabene berupa zat berbahaya dan beracun, maka kesehatan kerja menjadi hal penting di perusahaan air minum. Hati-hati dalam bekerja. Laboratorium air penuh dengan zat kimia, ada yang eksplosif (mudah meledak), ada yang mudah terbakar, ada yang korosif, juga ada yang iritatif pada kulit dan paru-paru. Begitu pun di gudang dan suspenser. Pegawai yang bekerja di dua jenis ruang tersebut, yaitu laboratorium dan gudang sebaiknya lebih diperhatikan kesehatannya. Jangan sampai terjadi, kantor PDAM seolah-olah menjadi medan "perang” seperti di Suriah akibat penggunaan klorin untuk maksud baik, yaitu disinfeksi tetapi menjadi the killing field secara diam-diam bagi karyawannya.

Bagi masyarakat Indonesia yang masih punya hati nurani, mari berdoa agar penguasa Suriah segera dimintakan tanggung jawabnya oleh PBB dalam pembantaian dengan klorin seperti yang mereka lakukan pada tahun 2016 di Aleppo. Adapun pemerintah Indonesia semoga dibukakan hatinya dan ikut negara lain yang mengecam dan menghukum penguasa Suriah atas kebiadabannya.

Akhir kata, bumi ini kaya akan zat kimia yang bermanfaat untuk kehidupan manusia, hewan dan tumbuhan, tetapi bisa berubah menjadi zat berbahaya kalau tidak hati-hati dalam menanganinya atau berada di tangan penguasa yang zalim tanpa hati nurani. * 